\title{
Household and Contextual Factors Influencing Payment of Education by Households in Ghana
}

\author{
Anthony Abbam \\ Department of Economics Education \\ University of Education, Winneba, Ghana
}

Doi: 10.19044/esj.2018.v14n1p258 URL:http://dx.doi.org/10.19044/esj.2018.v14n1p258

\begin{abstract}
Using data from the sixth round of the Ghana Household Living Standards Survey, this paper examines issues relating to household educational expenditure with a view to deriving implications for policy direction. The key findings from the estimated Tobit model in this paper are as follows: First, household income has significant positive influence on household expenditure on education. Thus, increase in household income is associated with an increase in educational expenditure. Second, there was a negative significant relationship between household poverty and demand for education. Third, female headed household is a positive significant determinant of expenditure on education. Finally, contextual factors such as locality are very crucial in determining household educational expenditures. The paper recommends for equality of educational opportunity so that children from economically handicapped families and less endowed communities have the same playing field as their well-to-do counterparts. Further, policy strategies to improve income generating activities of households should be pursued and the design of schemes specifically to offer assistance for those who are economically vulnerable.
\end{abstract}

Keywords: Household, Education Expenditure, Contextual Factors, Tobit estimation models, Ghana

\section{Introduction}

The role of education in socioeconomic development of countries around the globe notably developing economies has received significant attention in the literature and policy circles. Education has been described as the process of acquiring knowledge, skills, values and attitudes to fully develop individual capacities for societal wellbeing (GLSS-6, 2014). Thus education and investment in human capital have become vital drivers of economic growth and development. Through education people obtain 
requisite knowledge, skills and expertise which increase their productive capacity thereby enhancing economic growth and development. Besides, investment in human capital can help households to avoid the poverty trap and enhance social standing. This lays credence to the significance policymakers attached to expenditure on education since it has implications for employment, earnings and societal development. Further, an increase in the number of welleducated people connotes a higher level of labor productivity and a greater ability to absorb and apply advanced technology from developed countries (Acemoglu, 2009).

Considering the critical role of education in nation building and national development countries particularly developing economies have over the years continue to introduce policy reforms in the education sector. According to United Nations (2014), the introduction of educational policies and programs aimed at reforming the educational sector in Ghana, dates back in the colonial era. This reform process continued through to the educational policies of the late 1980s, to the introduction of the free compulsory universal basic education (FCUBE) in 1996, the Capitation Grant Scheme in 2005 among others. In addition, the Free Senior High School Programme has been introduced in 2017. Although these reforms have had tremendous effect on educational outcomes, the education sector in Ghana is saddled with various challenges which tend to militate against attaining the goals of these education policy reforms. Mention can be made of limited access and low enrolments especially for the poor and females (Government of Ghana, 1997). This makes the policy goal of achieving universal basic education an illusion to some sections of the society.

The United Nations (2014) estimates that 103 million youth worldwide lack basic literacy skills while 57 million children worldwide are still out of school with more than half living in sub-Saharan Africa. In Ghana, nearly halfa-million children of primary school going age are out of school, while over 11 per cent of adolescents within the lower secondary school going age are not in school (World Bank WDI, 2016). Besides, close to one-fifth of the adult population in Ghana have not experienced schooling (Ghana Statistical Service, 2014). Arguably, a greater percentage of the cost of education is largely public funded, however, there may be indirect costs of education known as the opportunity costs, which are the income or the child's labour the household loses when a child is enrolled in school (Bray and Bunly, 2005). The opportunity cost of schooling is largely determined by the rewards to and availability of child labour. Also, Bray and Bunly (2005) maintain that household demand for school reflects the net benefit, which may be linked to the perceived quality of provision and possible future earnings. Thus educational costs can create a disincentive for children from poor households to access schooling. This paper thus, seeks to provide an insight on the main 
determinants of households' demand for education with a particular emphasis on households' educational expenditures in order to provide empirical relevance to policies and programmes designed to achieve equitable access to education all categories of people.

The overarching objective of this study is to investigate the determinants of education expenditure pattern of Ghanaian households. Although Ghana provides a unique socio-economic and demographic context for examining household education expenditure, prior empirical research on the subject is very scanty (Donkohand Amikuzuno, 2011; Iddrisu et tal, 2017). Using the recent data from GLSS-6 has the potential of providing a better picture and understanding of household educational expenditures. Although, most extant literatures have used educational attainment as a proxy for educational demand (e.g. Pushkar, 2003; Li and Min, 2001), educational attainment cannot capture the demand for education wholly since educational attainment also depends on the child's ability (Qian and Smyth, 2011). Therefore, a study which focuses on educational expenditure would be advantageous as the willingness of households to pay for their children's education can easily be measured. Finally, most past studies in developing countries have used standard OLS or logistic regression model to analyse educational expenditure (Okuwa, et al, 2015 and Ogundari \& Abdulai, 2014) in Nigeria; (Donkoh and Amikuzuno, 2011) in Ghana and (Tansel and Bircan, 2006) in Pakistan. Ignoring this censoring aspect in the data will result in bias coefficients. This study contributes to existing body of knowledge by applying the Tobit model for the analysis of educational expenditure.

The rest of the study is organized as follows. Section two of the paper is dedicated to the literature review of the determinants of household education expenditure. The third section presents the data and methodology. Section four includes the discussions of the empirical results. Finally, conclusion and policy implications of the study are presented in section five.

\section{Literature}

Generally, a household's decision to invest in education is usually influenced by plethora of factors such as the level of household income, employment status and education of parents, number of children in the household, location of households, the age of the children and gender of the household head among others (Psacharopoulos and Robert, 2000; Gulosino and Tooley, 2002; Tilak, 2002; Colclough et al. 2003; Qian and Smyth, 2010; Choudhury, 2011; Lakshamanasamy, 2006). With regard to income, a study by Gürler et al, (2007) on determinants of education demand in Turkey show that higher income households spend more on children education. Other studies that confirmed the positive association of education demand and household income include (Qian and Smyth, 2011; Vu, 2012; Donkoh and 
Amikuzuno, 2011; Iddrisu et tal, 2017). However, using data from Japanese households to examine the determinants of educational expenditure Hashimoto and Health (1995) found that the income educational expenditure elasticity is high among households with a middle range of income, lower with low-income households. On employment status, evidence in general shows those children whose parents are in some form of employment invest more in education. According to Huy (2012) households whose heads have professional jobs enhances the probabilities of increased educational expenditure. A similar study in China by Qian and Smyth (2011) showed that when fathers are working in professional occupations spend more on education. For parental education, Qian and Smyth (2011) analyzed survey data from 32 selected cities across China in 2003 and indicated that households where mothers have senior secondary school or college education, are likely to spend more on education. Also, Huy (2012), examining the determinants of educational expenditure in Vietnam established that parental education significantly influence educational expenditure. Besides, households with more primary-school-age or secondary-school-age children spend more on education, while households with pre-school-age or college-age children spend less on education. In the same vein, Knight and Shi (1996) used household sample survey and observed that parents' educational attainment is the most important factor influencing children's education. They also indicated that father's education is more important factor than mother's education. Using household survey data from Nigeria to analyze the determinants of household's education and health care spending in Nigeria (Ogundari and Abdulai, 2014) indicated that household size positively and significantly drive households' decisions on whether to spend and how much to spend on educational and healthcare services. Donkoh and Amikuzuno (2011) in their study of the determinants of household education expenditure in Ghana observe that households whose heads are relatively young and those whose heads have formal education as well as ownership of land, bus and other durable assets have greater probability of spending on education. Another study in Ghana observed that large-sized households spend more in terms of educational expenses than small-sized households reflecting largely the quantity of education purchased, given that quality and contextual factors matter for educational investments (Iddrisu et tal, 2017). Rural-urban dichotomy plays a critical role in determining household expenditure on education. Glewwe and Patrino (1999) opine that there is a stronger tendency for households in urban areas to spend more resources in educating their children relative to rural households. Similarly, Tansel and Bircan (2006) suggest that urban households invest more in the schooling of their children than rural dwellers. Ogundari and Abdulai (2014) observe that relative to male-headed households, female-headed households tend to spend more on 
the education of household members and health-care services. From the above, while vast literature exists on the determinants of households' educational expenditures, not much attention has been devoted to the subject in Ghana.

\section{Data and Methodology}

The Ghana Living Standards Survey Six (GLSS-6) was used to undertake this study. Data collection was undertaken by the Ghana Statistical Service which is the statutory body mandated to collect official national data. The Ghana Living Standards Survey Six (GLSS-6) conducted in 2012/2013 is the most current data set available. It focuses on the household as the key socio-economic unit and provides valuable information on the living conditions and well-being of households in Ghana. The survey covered a nationally representative sample of 18,000 households in 1,200 enumeration areas. Out of the 18,000 households, 16,772 were successfully enumerated leading to a response rate of 93.2 percent. Detailed information was collected on the Demographic characteristics of households, Education, Health, Employment, Migration and Tourism, Housing conditions, Household Agriculture, Household Expenditure, Income and their components and Access to Financial Services, Credit and Assets.

The sample size for the estimation of determinants of household education expenditure was obtained by merging three data files with information on the income of the household, household poverty and general household conditions. It was observed that not all households relevant the information on the other variables which were included in the model; hence a final sample size of 7,892 was used for this study.

In order to examine the factors that affect the household educational expenditure, the Tobit model was employed as proposed by Tobin (1958) for the analysis of censored data. Given that in most cases the amount spent on educational items by considerable numbers of poor families is zero, an empirical estimation strategy that ignores this left censoring in the data may result in bias estimates. The current study follows the specification of Huy (2012), which involves the use of the Tobit model to empirically analyse the determinants of household educational expenditures. Censoring households with zero educational expenditure, the model can be specified as:

$$
\begin{aligned}
& y_{i}^{*}=\beta x_{i}+\varepsilon_{i}-----------------------------------------(1) \\
& \varepsilon \mid x_{i} \square N\left(0, \sigma^{2}\right)
\end{aligned}
$$

Household educational expenditure $\left(y_{i}\right)$ can be expressed as follows:

$$
y_{i}= \begin{cases}y_{i}^{*}, & \beta x_{i}+\varepsilon_{i}>0 \\ 0, & \beta x_{i}+\varepsilon_{i} \leq 0\end{cases}
$$

where $y_{i}^{*}=$ latent dependent variable 
$x_{i}=$ the vector of independent variables

$\beta=$ the vector of coefficients

$\varepsilon_{i}=$ error term and

$N=$ the number of observations.

The empirical model can be written as follows:

$\ln$ HEExpenditute $=\beta_{0}+\beta_{1}$ gender $+\beta_{2}$ HHsize $+\beta_{3}$ PovStatus $+\beta_{4}$ EmpStatus $+\beta_{5}$ Re sidence

$+\beta_{6}$ HighestEduc $+\beta_{7}$ Television $+\beta_{8} \ln$ Income $+\beta_{9}$ House

$+\beta_{10} \ln$ PerCapitaCons $+\beta_{11}$ Locality $+\varepsilon$

where $\ln$ HEExpenditure is the logarithm of household education expenditure as in equation (3) and is measured as in Ghana Cedis, gender is coded 1 for female and 0 for otherwise, Hhage is the age of household head in years, Hhsize is the household size which involves the number of people who eat from the same pot, PovStatus measures household poverty status and is coded 1 for very poor, 2 for poor and 3 for non poor; EmpStatus is the employment status of the household head and it takes a value of 1 for household heads employed in public sector employment; 2 for those in formal private employment, 3 for those who are self-employed and 4 for those who are unemployed; Re sidence is the household place of residence and is coded 1 for rural and 0 for urban, HighestEduc measures the educational attainment of the household head and it takes a value of 0 if the head has no schooling record; 1 if head's highest educational attainment is primary; 2 if head's highest educational attainment is secondary and 3 if head's highest educational attainment is tertiary, Television is the ownership of television by the household, ln Wage is the log of household wage income measured in Ghana cedis, House is ownership of dwelling place by household head, In PerCapitaCons is the real per capita consumption of the household and Locality is the locality of the household head and it takes the value 1 for household heads located in the north and 0 for south.

\section{Empirical Results}

From Table 1, it can be noted that about $72 \%$ of households are headed by males with a standard deviation of 0.4499 . This shows male dominance in household decision-making in Ghana. 
Table 1: Descriptive Statistics of Explanatory Variables

\begin{tabular}{|c|c|c|c|c|}
\hline Variable & Mean & $\begin{array}{l}\text { Standard } \\
\text { Deviation } \\
\end{array}$ & Minimum & Maximum \\
\hline InEducationExpen & 5.8259 & 1.6987 & 1.2039 & 11.0048 \\
\hline \multicolumn{5}{|l|}{ Gender } \\
\hline Female & 0.2819 & 0.4499 & 0 & 1 \\
\hline Male & 0.7180 & 0.4499 & 0 & 1 \\
\hline HhSize & 4.3349 & 2.7869 & 1 & 29 \\
\hline \multicolumn{5}{|l|}{ Poverty Status } \\
\hline Very Poor & 0.1000 & 0.3000 & 0 & 1 \\
\hline Poor & 0.1432 & 0.3503 & 0 & 1 \\
\hline Non Poor & 0.7567 & 0.4290 & 0 & 1 \\
\hline \multicolumn{5}{|l|}{ Employment Status } \\
\hline Employed Public & 0.0728 & 0.2598 & 0 & 1 \\
\hline Employed Private & 0.1392 & 0.3461 & 0 & 1 \\
\hline Self-Employed & 0.6826 & 0.4655 & 0 & 1 \\
\hline Unemployed & 0.1054 & 0.3071 & 0 & 1 \\
\hline \multicolumn{5}{|l|}{ Place of Residence } \\
\hline Rural & 0.5561 & 0.4969 & 0 & 1 \\
\hline Urban & 0.4439 & 0.4969 & 0 & 1 \\
\hline \multicolumn{5}{|l|}{ Educational Level } \\
\hline No Education & 0.2772 & 0.4476 & 0 & 1 \\
\hline Primary & 0.2157 & 0.4113 & 0 & 1 \\
\hline Secondary & 0.3739 & 0.4839 & 0 & 1 \\
\hline Tertiary & 0.1331 & 0.3397 & 0 & 1 \\
\hline \multicolumn{5}{|l|}{ Television } \\
\hline No & 0.5200 & 0.4996 & 0 & 1 \\
\hline Yes & 0.4799 & 0.4996 & 0 & 1 \\
\hline lnWage Income & 8.002 & 1.3639 & 0 & 14.0191 \\
\hline \multicolumn{5}{|l|}{ House Ownership } \\
\hline No & 0.4618 & 0.4986 & 0 & 1 \\
\hline Yes & 0.5382 & 0.4986 & 0 & 1 \\
\hline Real Per Capita Consumption & 6.5126 & 1.0681 & 0.8233 & 8.8987 \\
\hline \multicolumn{5}{|l|}{ Locality } \\
\hline South & 0.7224 & 0.4479 & 0 & 1 \\
\hline North & 0.2776 & 0.4479 & 0 & 1 \\
\hline
\end{tabular}

Source: Authors' computations based on GLSS 6 data 
The descriptive statistics also show that the average number of household members is about 4 and it varies from 1 to 29 . From the results, about $76 \%$ of households were not poor with about $14 \%$ being poor and about $10 \%$ falling within the very poor category. About $68 \%$ of household heads are in self-employment, about $14 \%$ are in private formal employment, about $7 \%$ work in the public sector and about $10 \%$ are unemployed. The results indicate that about $56 \%$ of households live in rural areas while $44 \%$ reside in urban areas. This goes to suggest that most communities in Ghana are rural based. With regard to educational attainment, about $28 \%$ of household heads have no education, $22 \%$ have had primary education, and $37 \%$ with secondary education and $13 \%$ have attained tertiary education. About $48 \%$ households own television while $52 \%$ did not have television. The descriptive statistics indicate that about $54 \%$ of households own houses while $46 \%$ did not have, thus showing the level of housing deficit in the country. On the average, a household spends GHф7.00 on food and non-items. In terms of locality, about $72 \%$ households are located in the Southern part of the country while $28 \%$ are located at the Northern.

Table 2 reports the Tobit regression results on the determinants of educational expenditure by household. It is found that being a female household head has a significant positive effect on education expenditure. As expected, household size has significant positive influence on education expenditure. Households with large family sizes tend to spend more on education. One probable reason may be that larger family size feeds into household budget, which might positively affect allocation of extra resources to education. However, one may argue that in households with large family size resources have to be distributed between more members, thereby reducing the availability of resources for education expenditures.

Poverty status of households had negative significant influence on the amount households' spend on education. From the results, very poor and poor households spend 1.1371 and 0.6015 times less than non poor households on education. Thus, for poor households, if sending a child to school takes up a large share of household income, then that decision could create a heavy burden and potentially lead to non-attendance (Akyeampong et al, 2007; Lewin, 2007). Therefore, it would be very difficult if not impossible for children from poor families to "catch up" with children from higher income families. This has the potential of resulting in low intergenerational socioeconomic mobility for such group of people. Educational attainment of the household head has significant mixed influence on households' educational expenditures. The results show that household heads with no education spend 0.6286 times less on education compared to those with tertiary education. This is probably due to their inability to appreciate the benefits of education. Whereas household heads who have had primary and 
secondary education spend 0.4979 and 0.2081 times more respectively on children's education. The effect of household heads educational attainment is consistent with findings of Huy (2012). This lends credence to the generally accepted notion that educated people are relatively more capable of understanding the benefits of education and for that matter are likely to invest more resources in the education of their children.

Table 2: Tobit Results of Determinants of Household Education Expenditure

\begin{tabular}{|c|c|c|c|c|}
\hline Variables & Estimate & $\begin{array}{l}\text { Standa } \\
\text { rd } \\
\text { Error }\end{array}$ & t-score & $\begin{array}{c}\text { P- } \\
\text { value }\end{array}$ \\
\hline $\begin{array}{c}\text { Gender } \\
\text { Female (Ref: Male) }\end{array}$ & $0.4689 * * *$ & 0.0364 & 12.89 & 0.000 \\
\hline HHsize & $0.2105 * * *$ & 0.0066 & 32.01 & 0.000 \\
\hline $\begin{array}{c}\text { Poverty Status (Ref: Non Poor) } \\
\text { Very Poor } \\
\text { Poor }\end{array}$ & $\begin{array}{l}-1.1371 * * * \\
-0.6015 * * *\end{array}$ & $\begin{array}{l}0.0601 \\
0.0446\end{array}$ & $\begin{array}{l}-18.93 \\
-13.50\end{array}$ & $\begin{array}{l}0.000 \\
0.000\end{array}$ \\
\hline $\begin{array}{l}\text { Employment Status (Ref: } \\
\text { Unemployed) } \\
\text { Employed Public } \\
\text { Employed Private } \\
\text { Employed Self }\end{array}$ & $\begin{array}{c}0.1577 \\
-0.0332 \\
-0.2101 *\end{array}$ & $\begin{array}{l}0.1108 \\
0.1054 \\
0.0983\end{array}$ & $\begin{array}{r}1.42 \\
-0.31 \\
-2.14\end{array}$ & $\begin{array}{l}0.155 \\
0.753 \\
0.033\end{array}$ \\
\hline $\begin{array}{l}\text { Highest Educational (Ref: Highe } \\
\text { Education) } \\
\text { No Education } \\
\text { Primary } \\
\text { Secondary }\end{array}$ & $\begin{array}{l}-0.6286 * * * \\
0.4979 * * * \\
0.2081 * * *\end{array}$ & $\begin{array}{l}0.0558 \\
0.0543 \\
0.0479\end{array}$ & $\begin{array}{c}-11.27 \\
9.17 \\
4.35\end{array}$ & $\begin{array}{l}0.000 \\
0.000 \\
0.000\end{array}$ \\
\hline $\begin{array}{c}\text { Television (Ref: Yes) } \\
\text { No }\end{array}$ & $0.0713 *$ & 0.0323 & 2.21 & 0.027 \\
\hline Income & $0.1311 * * *$ & 0.0122 & 10.72 & 0.000 \\
\hline $\begin{array}{c}\text { House Ownership (Ref: Yes) } \\
\text { No }\end{array}$ & 0.0132 & 0.0323 & 0.41 & 0.682 \\
\hline Real Per Capita Consumption & $1.0117 * * *$ & 0.0224 & 45.12 & 0.000 \\
\hline $\begin{array}{c}\text { Place f Residence (Ref: Urban) } \\
\text { Rural }\end{array}$ & $-0.6936 * * *$ & 0.0346 & -20.04 & 0.000 \\
\hline $\begin{array}{l}\text { Locality (Ref: North) } \\
\text { South }\end{array}$ & $0.5901 * * *$ & 0.0405 & 14.56 & 0.000 \\
\hline Constant & $4.4643 * * *$ & 0.1487 & 30.01 & 0.000 \\
\hline
\end{tabular}


Sigma

Observations

LR chi2(15)

Prob>chi2

Pseudo R ${ }^{2}$
1.2929

0.0102

7892

3877.00

0.0000

0.1266

Note: * significant at $10 \% ; * *$ significant at $5 \% ; * * *$ significant at $1 \%$ Source: Authors' computations based on GLSS Six Data

Exposure to mass media was measured using ownership of television. Households who do not own television spend only 0.0713 times more on education than those with television at a statistically significant level of $10 \%$. Exposure to the mass media enables household heads to have information about the happenings around the world in terms of returns on education and the importance of educating their children to the highest level. Household income has a significant positive effect on households' educational expenditures. This implies that higher income households tend to spend more on education. This is in line with findings of Huy (2012) and Qian and Smyth (2011). Ownership of assets such as a house is positively and significantly related to household education expenditure. The results show that household real per capita consumption expenditure is positively and statistically associated with educational expenditure of households.

From the results, contextual factors such as rural residence and locality of the household head are significant in explaining expenditure on education. Rural residence is significantly related to household expenditure on children's education. Households in rural areas spend 0.6936 times less on education of their children than those in urban areas. The implication is that households in urban areas investment more in their children's education since education returns are higher in such areas. Besides, urban centers are more likely to provide more educational opportunities and facilitate access. Further, the results indicate that southern households spend significantly more on children's education compared to their northern counterparts. The effect of contextual factors on expenditures incurred by households on children's education is in line with the descriptive statistics.

\section{Conclusion and Policy Implications}

The current paper examines the determinants of household educational expenditure by estimating a Tobit model. It was revealed that, household expenditure on education is determined by both household socio-economic characteristics and contextual factors. Thus household size has significant positive influence on education expenditure. Households need to be educated about the benefits of keeping small family sizes. The study found that rural households spend less on education. A major finding in this paper is that household poverty status had negative significant influence on educational 
expenditure. This has implications on intergenerational socioeconomic mobility for children from poor family background. Household heads with primary and secondary schooling record are increasingly more likely to invest in their children's education than those with no educational experience. Higher income households tend to spend more on education. Although accumulation of human capital is seen as an important conduit for getting out of the poverty trap the poor spend less on education. Finally, contextual factors are crucial for households' educational expenditures in Ghana. Based on the findings of the study, it is recommended that reforms in the educational system still need to focus extensively on reducing the barriers to access and instigating measures that could effectively improve the level of education in rural areas. Besides, given that poverty status is negatively associated with education expenditure reflects amount spent on education by households. Indeed, policy makers should endeavour to ensure equality of educational opportunities so that children from low education families have the same playing field as their well-to-do counterparts. Further, policy strategies to improve income generating activities of households should be pursued and the design of schemes specifically to offer assistance for those who are economically vulnerable.

\section{References:}

1. Abdul, M., Iddrisu, M, D., \& Quartey, P. (2017). Paying for education among households in Ghana: Is there any role for household resources and contextual effects? International Journal of Development Issues, $16(2), 214-226$.

2. Acemoglu, D. (2009). Introduction to modern economic growth, Princeton, NJ: Princeton University Press.

3. Akyeampong, K., Djangmah, J., Oduro, A., Seidu, A., \& Hunt, F. (2007). Access to basic education in Ghana: The evidence and the issues. Country Analytic Report. CREATE, CIE. Brighton: University of Sussex.

4. Aslam, M., \& Kingdon, G. G. (2008). Gender and household education expenditure in Pakistan. Applied Economics, 40(20), 2573-2591.

5. Becker, G. S. (1965). A theory of the allocation of time. Economic Journal, 75 (299), 493-517.

6. Becker, G. S., \& Lewis, H. G. (1973). On the interaction between the quantity and quality of children. Journal of Political Economy, 81(2), 279-288.

7. Becker, G. S., \& Tomes, N. (1986). Human capital and the rise and fall of families. Journal of Labour Economics 4(3), 1-39.

8. Bray, M., \& Bunly. S. (2005). Balancing the book: Household financing of basic education in Cambodia. Comparative Education 
Research Centre Monograph. (Series No. 4). Hong Kong: The University of Hong Kong.

9. Connelly, R., \& Zheng, Z. (2003). Determinants of school enrolment and completion of 10 to 18 year olds in China. Economics of Education Review, 22, 379-388.

10. Ghana Statistical Service (GSS) (2008). Report of the fifth round of the Ghana living standards survey (GLSS 5): Accra, Ghana.

11. Ghana Statistical Service (GSS) (2014). Ghana living standards survey round six (GLSS 6), Main Report, Accra.

12. Glewwe, P., \& Patrinos, H. (1999). The role of the private sector in education in Vietnam: evidence from Vietnam living standards survey. World Development, 27(5), 887-902.

13. Glick, P., \& Sahn, E. D. (2000). Schooling of girls and boys in a West African country: The effects of parental education, income, and household structure. Economics of Education Review, 19(1), 63-87.

14. Hanushek, E. A., \& Woessmann, L. (2010). Education and economic growth", in Peterson, P., Baker, E. \& McGraw, B. (Eds), International encyclopedia of education 2, 245-252. Elsevier: Oxford press.

15. Hashimoto, K., \& Health, J. A. (1995). Income elasticities of educational expenditure by income class: the case of Japanese households. Economics of Education Review, 14, 53 -71.

16. Huy, V. (2012). Determinants of educational expenditure in Vietnam. International Journal of Applied Economics, 9, 59-72.

17. Iddrisu, A. M., Danquah, M. \& Quartey, P. (2016). Analysis of school enrolment in Ghana: A sequential approach. Review of Development Economics, doi: 10.1111/rode.12302.

18. Jayachandran, U. (2002). Socio-economic determinants of school attendance in India, (Working Paper No. 103), Centre for Development Economics.

19. Khandker, R. S., Lavy, V., \& Filmer, D. (1994). Schooling and cognitive achievements of children in Morocco: can the government improve outcomes? (World Bank Discussion Paper No. 264), World Bank: Washington DC.

20. Knight, J., \& Shi, L. (1996). Educational attainment and the ruralurban divide in China, Oxford Bulletin of Economics and Statistics, 58, 83-117.

21. Lloyd, C. B., \& Blanc, A. K. (1996). Children's schooling in subSaharan Africa: the role of fathers, mothers, and others. Population and Development Review, 22 (2), 265-298.

22. Ogundari, K., \& Abdulai, A. (2014). Determinants of household's education and healthcare spending in Nigeria: Evidence from survey data. African Development Review, (26) 1, 1-

14. 
23. Okuwa, O., Bolaji, R. J., \& Olaoye, O. O. (2015). Determinants of household expenditure on education in Nigeria. Journal of Educational Review, 8(3), 278 - 284.

24. Pushkar, M. (2003). Schooling and educational attainment:Evidence from Bangladesh. Education Economics, 11(2), 129-153.

25. Qian, X. J., \& Smyth, R. (2011). Educational expenditure in urban China: Income effects, family characteristics and the demand for domestic and overseas education. Applied Economics, 43(24), 3379-3394.

26. Sackey, H. A. (2007). The determinants of school attendance and attainment in Ghana: A gender perspective, (AERC Research Paper 173). Africa Economic Research Consortium, Nairobi, Kenya.

27. Schaffner, A. J. (2004). The Determinants of schooling investments among primary school aged children in Ethiopia. The World Bank, Africa Region Human Development Working Paper Series, Background Paper for the 2004 Ethiopia Education Country Status Report.

28. Tansel, A. (1997). Schooling attainment, parental education, and gender in Cote d'Ivoire and Ghana, Economic Development and Cultural Change, 45(4), $825-856$.

29. Tansel, A. \& Bircan, F. (2006). Demand for education in Turkey: A Tobit analysis of private tutoring expenditures. Economics of Education Review, 25(3), 303-313.

30. Tobin, J. (1958). Estimation of relationships for limited dependent variables, Econometrica, 26(1), $24-36$.

31. World Bank (2016). World Development Indicators Database. The World Bank.

32. Zimmerman, J. F. (2001). Determinants of school enrolment and performance in Bulgaria: The role of income among the poor and rich. Contemporary Economic Policy, 19(1), 87-98. 